\title{
Ontogenetic stages of ceratopsian dinosaur Psittacosaurus in bone histology
}

Qi Zhao, Michael J. Benton, Shoji Hayashi, and Xing Xu

Acta Palaeontologica Polonica 64 (2), 2019: 323-334 doi:https://doi.org/10.4202/app.00559.2018

The early ceratopsians Psittacosaurus and Protoceratops have provided important information on dinosaurian development because of abundant specimens of adults, subadults, juveniles, and even hatchlings. Here we present new data and methods for identifying key growth stages from bone histology. Previous studies on Psittacosaurus lujiatunensis from the Early Cretaceous Jehol Biota of China did not present in-depth analysis of growth patterns. Based on a histological study of 43 thin sections from 17 individuals of this species, we recognize four histological ontogenetic stages, i.e., hatchling, juvenile, sub-adult, and adult, but no fully-grown stage. We estimate life history and longevity from diaphyseal growth line counts and other features of histology. We show that $P$. lujiatunensis grew fast in early stages (hatchling, juvenile, and subadult), according to the density of vascular canals and the different type of bone tissue; the deposition of parallel fibred bone tissue in the outer cortex of the subadult stage indicates that growth rate was slowing down. We introduce a new graphical method to estimate the occurrence and volumes of vascular canals from thin sections more accurately than current two-dimensional approaches.

Key words: Dinosauria, Ceratopsia, bone histology, ontogeny, growth patterns, longevity, Cretaceous, China.

Qi Zhao [zhaoqi@ivpp.ac.cn] and Xing Xu [xu.xing@ivpp.ac.cn], Key Laboratory of Vertebrate Evolution and Human Origins, Institute of Vertebrate Paleontology and Paleoanthropology; and Center for Excellence in Life and Paleoenvironment, Chinese Academy of Sciences, Beijing 100044, China. Michael J. Benton [Mike.Benton@bristol.ac.uk], School of Earth Sciences, University of Bristol, Bristol BS8 1RJ, UK. Shoji Hayashi [hayashi@big.ous.ac.jp], Department of Biosphere-Geosphere Science, Okayama University of Science, Okayama, 700-0005, Japan. 
This is an open-access article distributed under the terms of the Creative Commons

Attribution License (for details please see creativecommons.org), which permits unrestricted use, distribution, and reproduction in any medium, provided the original author and source are credited.

\author{
For Full text $(1,969.0 \mathrm{kB})$ । \\ FDF
}

